\title{
"STRIATIONS" PRODUCED BY CATASTROPHIC SUBGLACIAL DRAINAGE OF A GLACIER-DAMMED LAKE, MJØLKEDALSBREEN, SOUTHERN NORWAY*
}

\author{
By Danny McCarroll, John A. Matthews, \\ (Department of Geology, University of Wales College of Cardiff, Cardiff CF1 3YE, Wales) \\ and RICHARD A. SHAKESBY \\ (Department of Geography, University College Swansea, Swansea SA2 8PP, Wales)
}

ABSTRACT. "Striations" produced by catastrophic subglacial drainage of an ice-dammed lake were investigated in front of Mjølkedalsbreen, Jotunheimen, southern Norway. At each site, length, width, and orientation of at least 50 "striations" were recorded. These data are compared with similar measurements from a glacially abraded "control" site. On the basis of length or width measurements alone, "striations" produced by subglacial drainage are not consistently distinguishable from those produced by glacial abrasion. However, the former display more variable orientations and cross-cutting relationships which could be misinterpreted as indicating changing ice-flow directions. They can be recognized by the occurrence of some "striations" with relatively low length: width ratios, which indicate the transport of boulders by saltation.

\section{INTRODUCTION}

The glacier Mjølkedalsbreen lies in south-eastern Jotunheimen, $8 \mathrm{~km}$ north-west of Lake Tyin (Fig. 1). Until

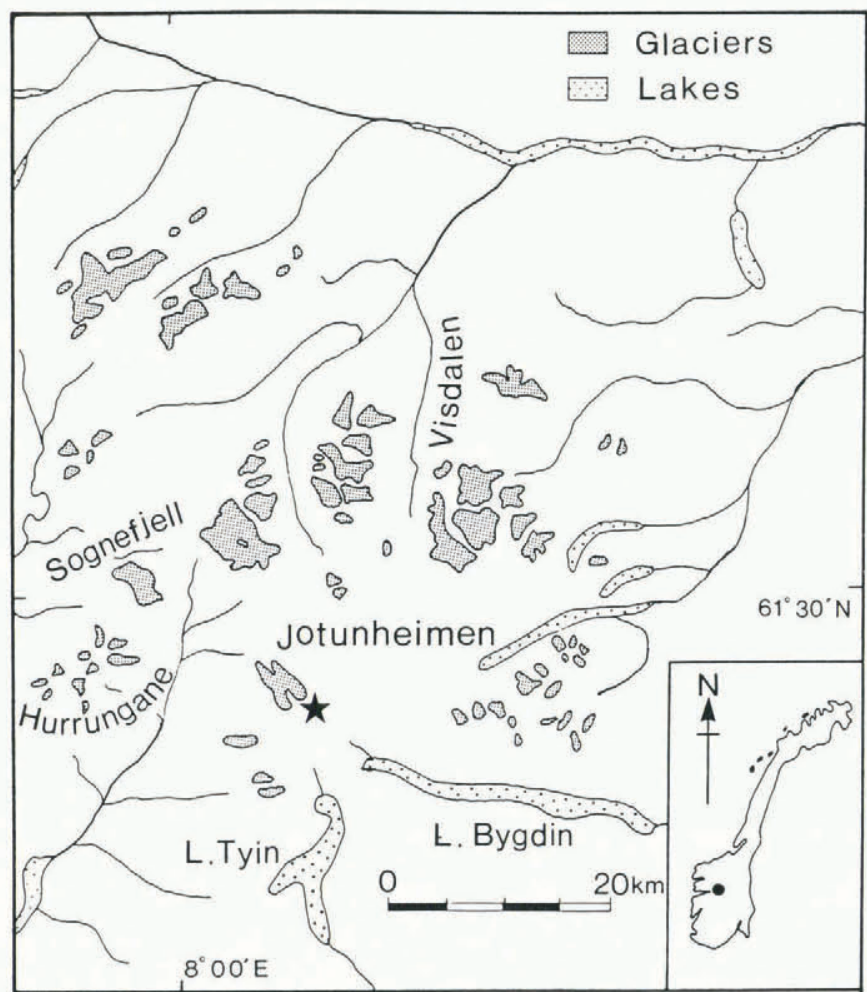

Fig. 1. Location of the glacier Mjolkedalsbreen (*) in Jotunheimen, southern Norway.
1937, the glacier snout extended across a series of connected valleys forming an ice dam at the southern end of Øvre Mjølkedalsvatn (Fig. 2). From about 1855 to 1937, catastrophic subglacial drainage of this lake occurred 17 times. The resulting catastrophic floods, or jökulhlaups, have been referred to by Sars (1869), Hertzberg (1878), Øyen (1893), Rabot (1905), Klæboe (1938), Liestøl (1956), and

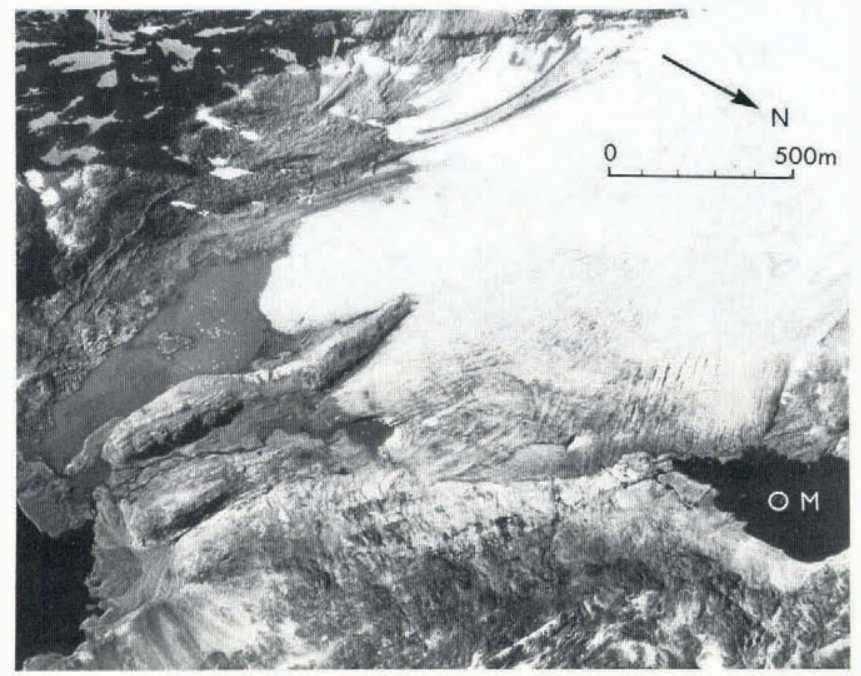

Fig. 2. Vertical aerial photograph showing pro-glacial area of Mjolkedalsbreen and the lake Ovre Mjolkedalsvatn (OM) which was previously dammed by the glacier. Sites 1-5 are located within the area of subglacial drainage.

Shakesby (1985). The geomorphological effects of the icedammed lakes and of the jökulhlaups have been discussed in some detail by Shakesby (1985), who mapped the routes of subglacial drainage from Øvre Mjølkedalsvatn and noted that they were characterized by "scoured bedrock, randomlyoriented scratches on ice-moulded rock surfaces and large rolled boulders" (p. 6). The purpose of this paper is to investigate in more detail the nature of the unusual scratches or "striations" (Fig. 3) and to discuss briefly their origin and significance.

\section{METHOD}

Five rock surfaces with well-developed "striations" were selected within the area of subglacial drainage. All surfaces were located on the north-east side of the valley on

*Jotunheimen Research Expeditions, Contribution No. 78. 


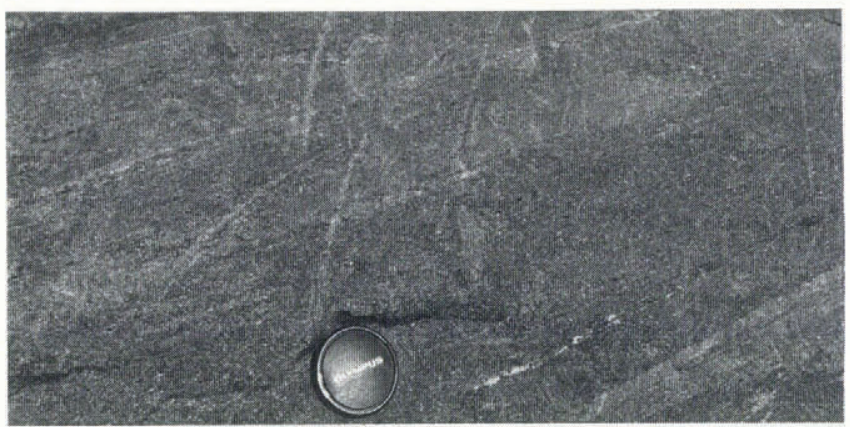

a

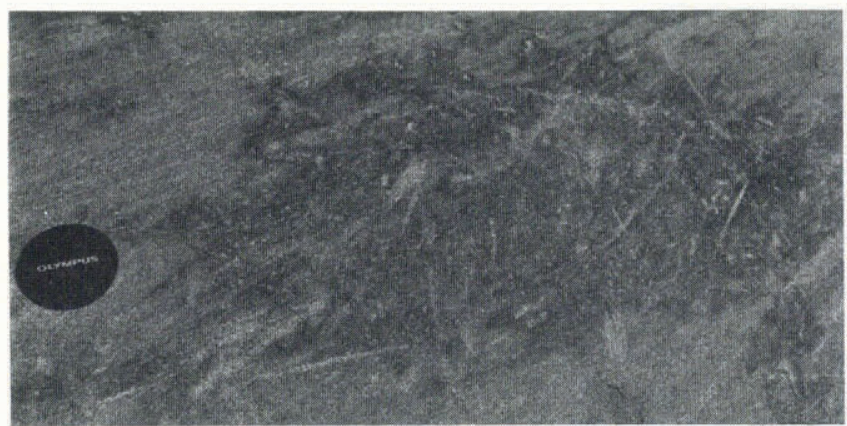

b

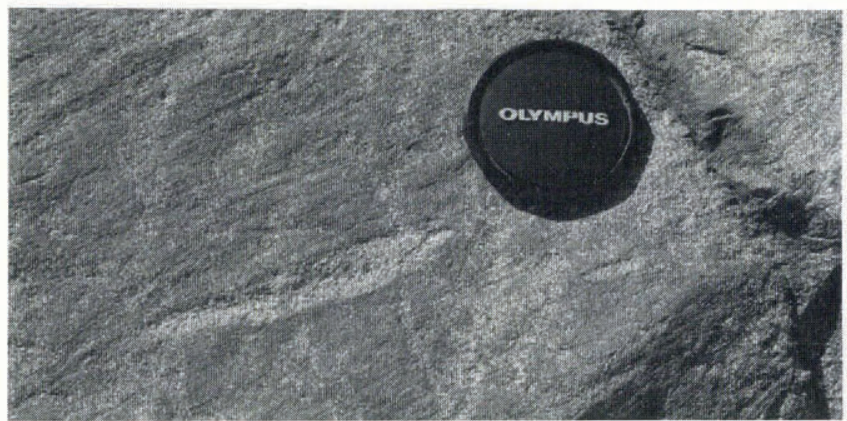

C

Fig. 3. "Striations" produced by catastrophic subglacial drainage. Note variable orientations and cross-cutting relationships ( $a$ and $b)$ and diagnostic short, wide, tapering "striations" (c) indicating transport of boulders in saltation.

pyroxene-granulite gneiss dipping from $8^{\circ}$ to $30^{\circ}$ to the south-west. These surfaces were previously covered by the glacier, which moved from west to east (Fig. 2). The orientation, length, and width of at least 50 "striations" were recorded at each site. Similar measurements were recorded from a sample of 50 striations on the glacially abraded surface to the south-east of the area of subglacial drainage. Subjective bias was minimized by restricting measurements to as small an area as possible and measuring every striation.

An attempt was also made to measure the maximum depth of each striation using a specially adapted engineer's dial gauge but, because of the very irregular surrounding surface, this proved difficult and unreliable. Most "striations" in the area of subglacial drainage appear, however, to be shallower than those at the glacially abraded control site.

\section{RESULTS}

\section{Orientation}

Orientation data are presented in Figure 4 as mirrorimage rose diagrams on which are included: inferred ice-flow direction, valley-axis alignment, preferred orientation, calculated using Curray's (1956) vectorsummation method, and the $A n_{180}$ statistic, which indicates
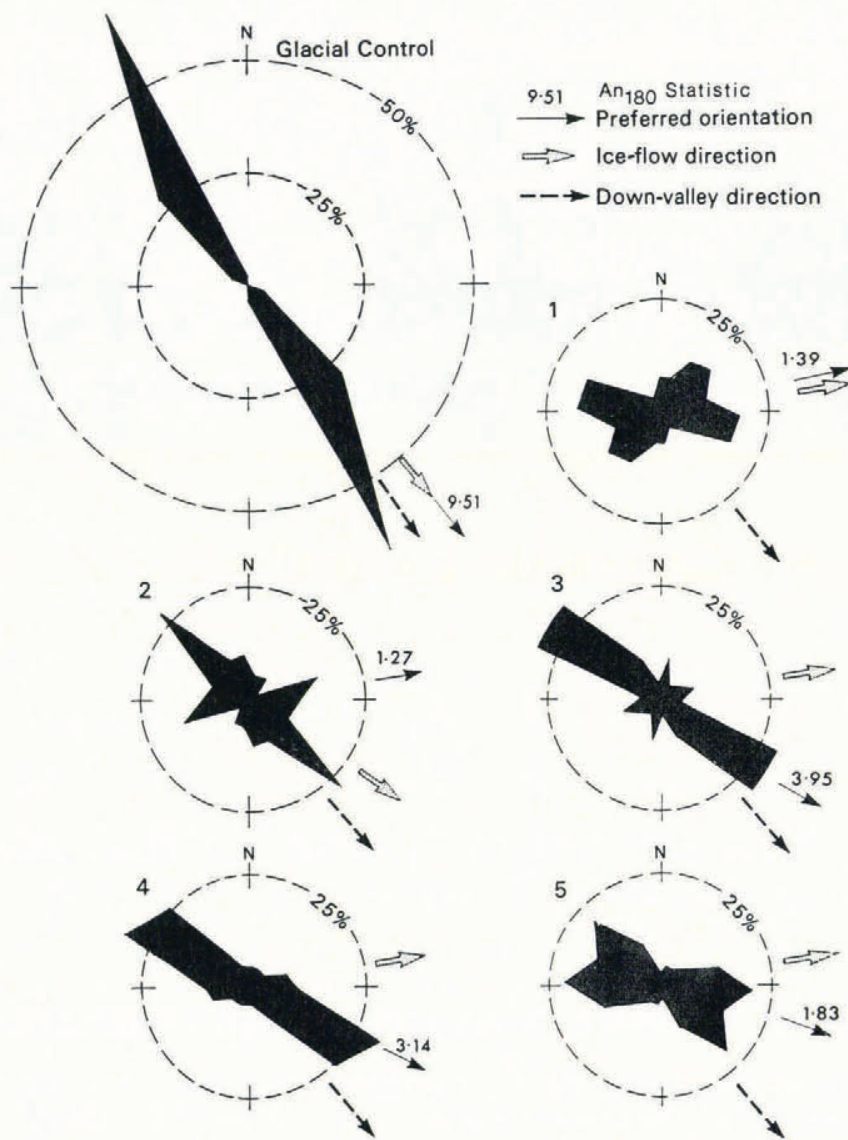

Fig. 4. Orientation data presented as mirror-image rose diagrams. Note that "striations" within the area of subglacial drainage have preferred orientations aligned between the down-valley direction and the direction of ice flow. The An ${ }_{180}$ statistic indicates the strength of the preferred orientation.

the strength and statistical significance of the preferred orientation (Dale and Ballantyne, 1980).

The striations at the glacial control site display a strong unimodal preferred orientation which parallels closely both inferred ice-flow direction and valley-axis alignment. In contrast, those of the subglacial drainage sites display wider distributions ranging from multi-modal to unimodal. The more variable orientation pattern is reflected by the much lower values of the $\mathrm{An}_{180}$ statistic (1.27-3.95) compared to that obtained from the "glacial" site (9.5). All of these values are, however, statistically significant $(p<0.05)$, confirming that the "striations" are not random but display a preferred orientation.

Of the subglacial drainage sites, only one site (site 1) displays a preferred orientation closely paralleling the iceflow direction in this part of the valley (inferred from contours on the retreating glacier). At this site the preferred orientation falls between the peaks of a bimodal distribution, so that very few of the "striations" are actually aligned at this angle. The preferred orientations obtained from the other four subglacial drainage sites all fall between the inferred ice-flow direction and the valley axis.

\section{Length}

The measurements of length at the subglacial drainage sites produced mean values ranging from 6.42 to $9.55 \mathrm{~cm}$ (Fig. 5). Although a larger mean value was obtained from the glacial control $(11.27 \mathrm{~cm})$, Kolmogorov-Smirnov twosample tests suggest that only at one of the five subglacial drainage sites are the "striations" significantly different from those of the "glacial" control site.

\section{Width}

Subglacial drainage sites yielded mean width values ranging from 3.3 to $7.2 \mathrm{~mm}$, compared to a value of $3.7 \mathrm{~mm}$ for the "glacial" site (Fig. 6). The "glacial" site displays a clear negative skew but the distributions obtained from the subglacial drainage sites range from a negative 

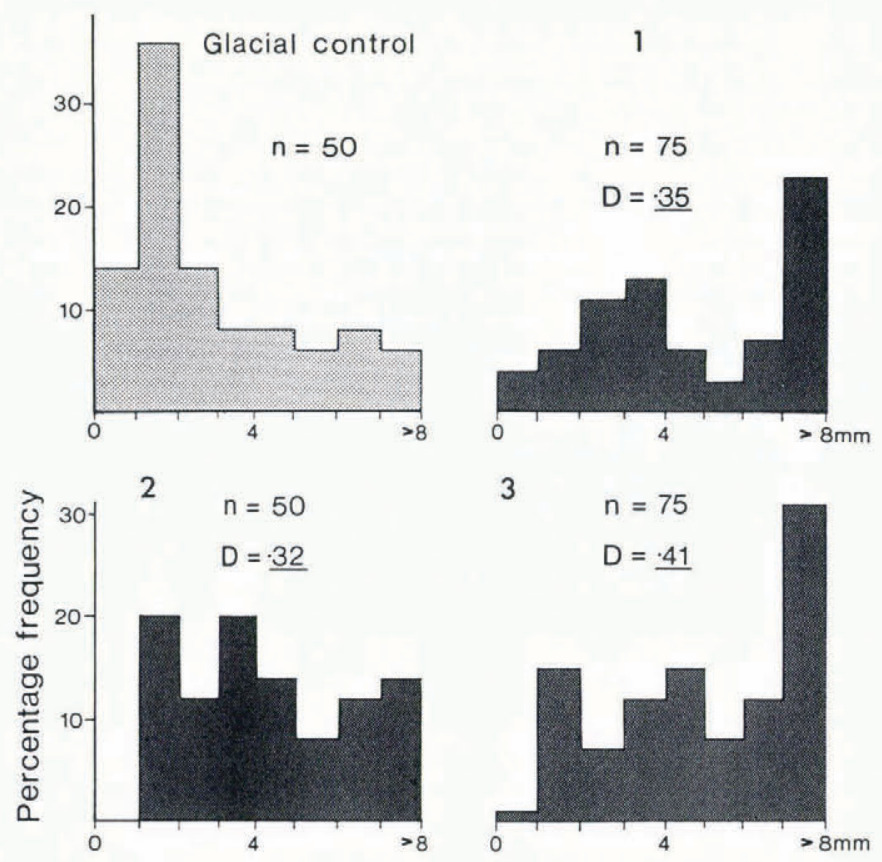

3
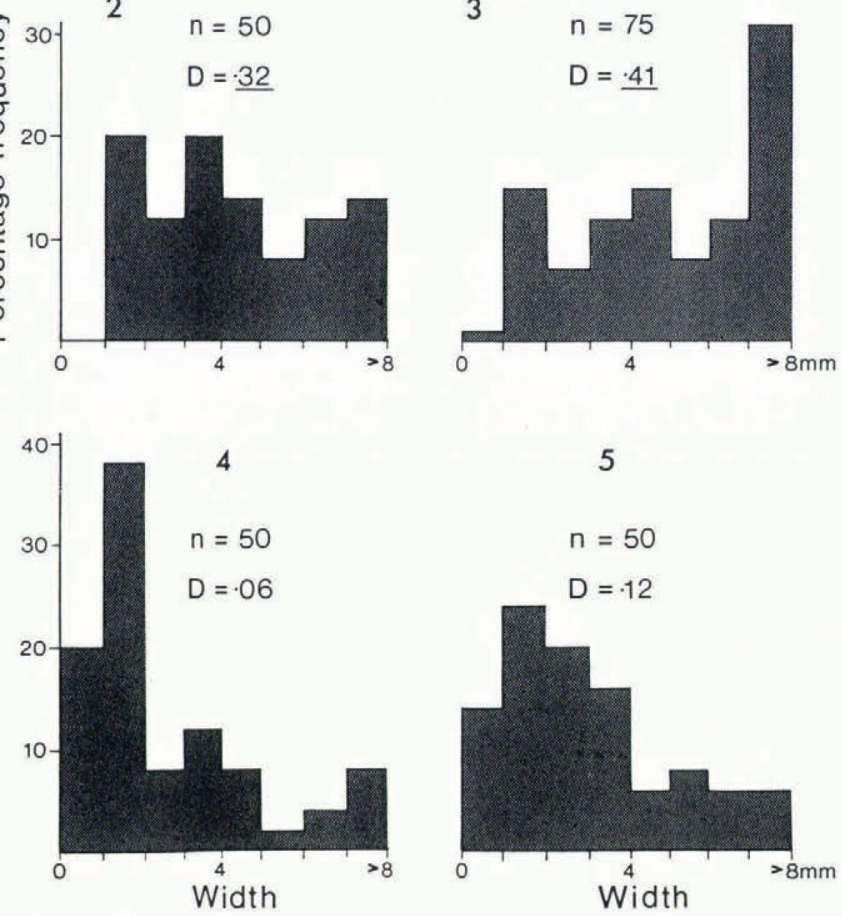

Fig. 5. Frequency distribution of length measurements of "striations" from the area of subglacial drainage compared to the "glacial" control site. $n=$ sample size, $D=$ maximum cumulative percentage difference; significant values are underlined (Kolmogorov-Smirnov two-sample test, $p<0.05$ ).

skew (sites 4 and 5) to a positive skew (sites 1 and 3 ). Of the five distributions, three are significantly different from that obtained from the glacial control site (KolmogorovSmirnov two-sample tests, $p<0.05$ ).

\section{Length : width ratios}

On the basis of length or width measurements alone, it is not possible consistently to distinguish glacially abraded striations from those produced by catastrophic subglacial drainage. However, if the ratio of length to width of each striation is used, a clear distinction emerges (Fig. 7). Although all sites display a negative skew, the glacial control is unique in comprising no striations with a length : width ratio $<10$. At the subglacial drainage sites, "striations" with a length: width ratio $<10$ comprise between 18 and $38 \%$ of the sample. Using the class intervals in Figure 7, four of the five subglacial drainage samples are significantly different from the glacial control site (Kolmogorov-Smirnov two-sample test, $p<0.001$ ). The fifth site (site 4) also yielded significantly different length: width ratios when a narrower class interval was introduced $(p<0.05)$, a procedure that is acceptable since this particular test may obscure differences when the data are cast into too few classes (Siegel, 1956).

\section{INTERPRETATION}

The samples of "striations" found in the pathways of subglacial drainage differ from those produced by glacial
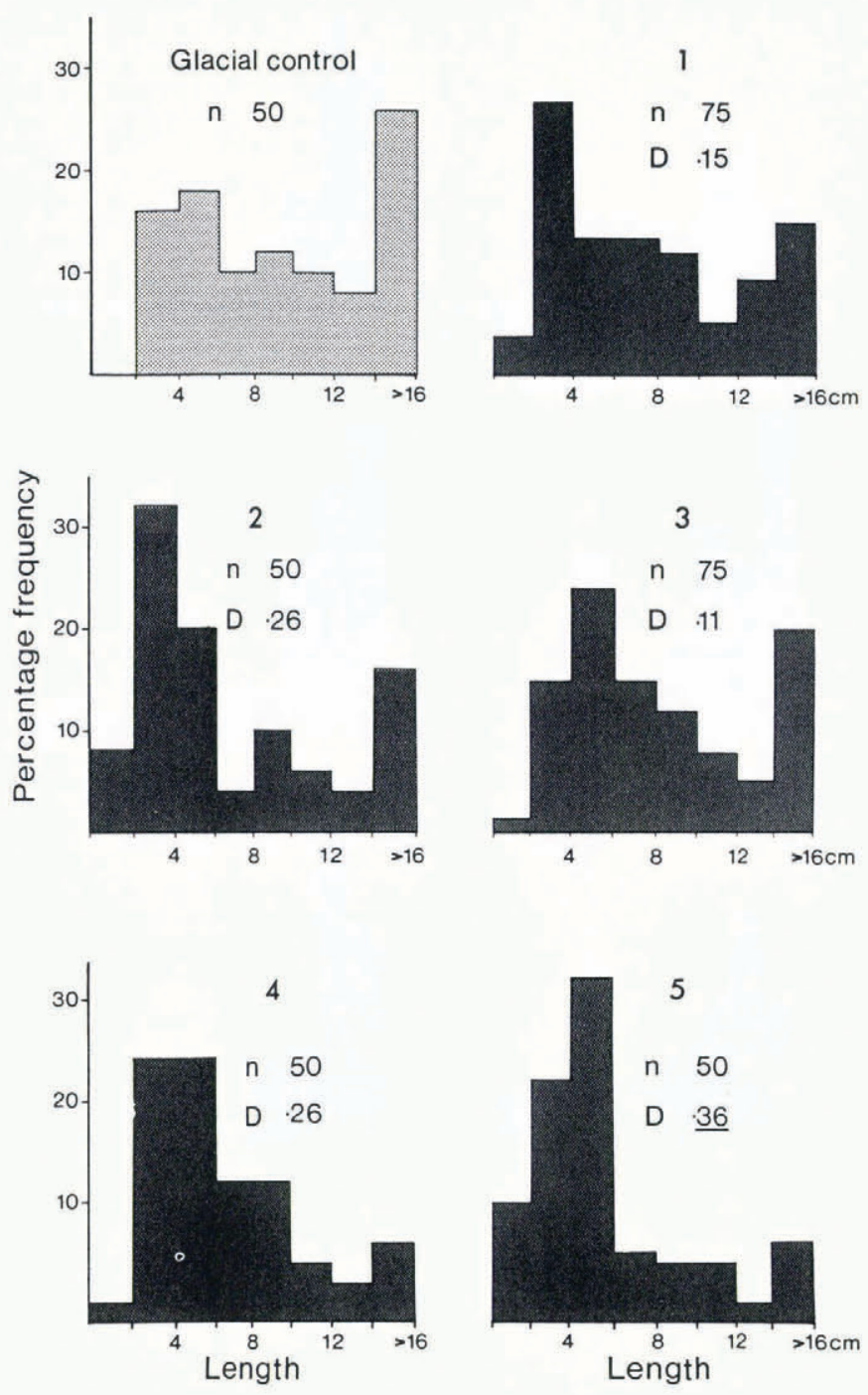

Fig. 6. Frequency distribution of width measurements of "striations" from the area of subglacial drainage compared to the "glacial" control site. $n=$ sample size, $D=$ maximum cumulative percentage difference, significant values are underlined (Kolmogorov-Smirnov two-sample test, $p<0.05$ ).

abrasion in that their orientations are more variable and a large minority of the "striations" have particularly low length: width ratios. These short, wide "striations" are apparent in Figure 3. Since they commonly taper towards one end, they imply a striking blow rather than steadily applied pressure, as would be caused by debris in traction at the sole of a glacier. The presence of these unusual "striations" suggests that saltation, sensu lato (taken to mean leaping and bouncing rather than rolling or movement in suspension), is an important transporting process during subglacial jökulhlaup release.

Some of the "striations" measured at the subglacial drainage sites may have been formed by subglacial abrasion prior to the period of catastrophic subglacial drainage. However, the fact that the majority show a much less consistent orientation and exhibit a preferred orientation, aligned not with ice movement but closer to the local down-valley direction, indicates that most of the "striations" have resulted from subglacial drainage rather than direct glacial action. It seems, therefore, that the enormous hydrostatic pressures which result from the catastrophic subglacial drainage of an ice-dammed lake can, through the abrasive action of boulders in traction, produce "striations" similar in form but with more variable orientations than those produced by subglacial abrasion.

\section{IMPLICATIONS}

Striations produced by glacial abrasion are well known 

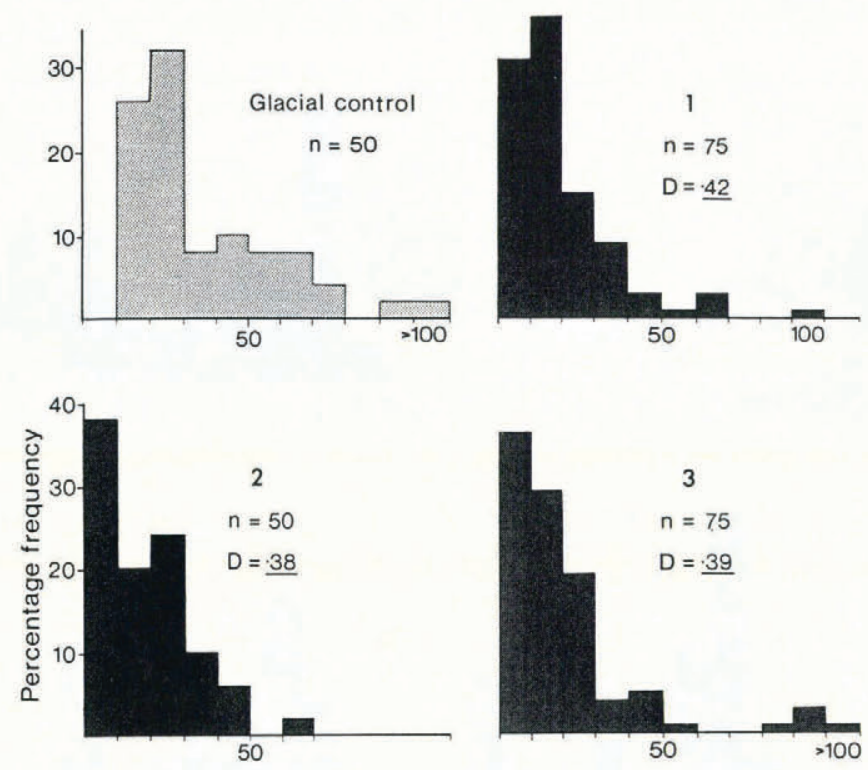

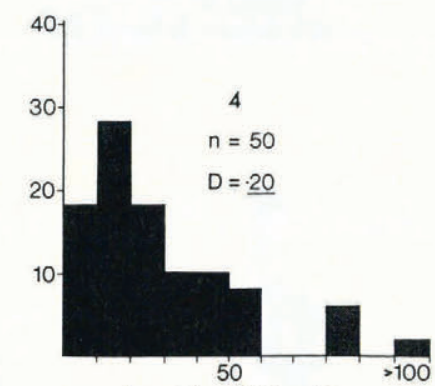

Length: width ratio

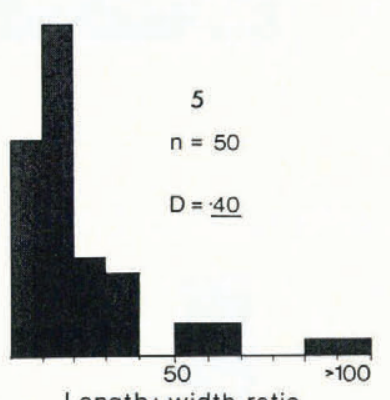

Length: width ratio
Fig. 7. Frequency distribution of length: width ratios of "striations" from the area of subglacial drainage compared to the "glacial" control site. $n=$ sample size. $D=$ maximum cumulative percentage difference; significant values are underlined (Kolmogorov-Smirnov two-sample test, $p<0.05$ ).

(Carol, 1947; Rastas and Sepälä, 1981). That "striations" can be produced by processes other than glacial abrasion has been recognized since the earliest days of glacial geomorphology (Agassiz, 1838). Scratches produced by massmovement processes such as mud flows (Sharp, 1938) and by sliding snow (Dyson, 1937; Costin and others, 1973) have been documented (Embleton and King, 1975, p. 184). The most important non-glacial "striations", however, are probably the abrasion marks produced along shorelines by the action of debris-laden floating ice. Although these features have been recognized for more than a century (see Dionne, 1973, 1985, for a review), their importance as possible sources of confusion in the reconstruction of glacier-flow directions has been stressed only recently. Dionne referred to a number of cases where multidirectional "striations" produced by drifting ice had previously been attributed to changes in the direction of glacier flow.

Although providing no quantitative results, Dionne $(1973,1985)$ suggested that "striations" produced by drifting ice possess a number of characteristics which distinguish them from glacial striations. They cover small areas, are multi-directional, short, shallow, discontinuous, and irregular. He also suggested that they are usually found on soft rocks such as shale, sandstone, limestone, and basalt, and only occasionally on hard rocks such as granite and gneiss. Perhaps the most useful diagnostic criterion is that they are restricted to modern and ancient shorelines.

The abrasion features described here as the result of catastrophic subglacial drainage of an ice-dammed lake are potentially even more misleading as they occur on hard rock surfaces and are characterized by a spread of orientations and cross-cutting relationships which might be interpreted as indicating changing ice-flow directions. Unlike those produced by drifting ice, however, the geographical distribution of "striations" produced by subglacial drainage may not be as readily recognized or as narrowly restricted, although from this study "striations" with a relatively low length: width ratio would appear diagnostic. Moreover, the catastrophic release of an ice-dammed lake may not be the only process whereby sufficient hydrostatic pressure is generated subglacially to produce similar abrasion marks. Care should be taken, therefore, when attempting to interpret cross-cutting "striations" in areas where production by subglacial drainage is a possibility. In particular, "striations" at sites where the presence of short, wide, tapering abrasion marks indicates the transport of boulders by saltation, should be interpreted with caution.

\section{ACKNOWLEDGEMENTS}

The research for this paper was carried out on the joint University College Cardiff and University College Swansea Jotunheimen Research Expedition of 1986. We would like to thank L. Zelinka for assistance in the field and the Cartographic Unit of the Department of Geography, University College Swansea, for preparing Figure 4. Helpful comments were received from two anonymous referees.

\section{REFERENCES}

Agassiz, L. 1838. On the polished and striated surfaces of the rocks which form the bed of glaciers in the Alps. Proc. Geol. Soc. London, 3, 321-322.

Carol, H. 1947. Formation of roches moutonnées. J. Glaciol., 1(2), 57-59.

Costin, A.B., J.N. Jennings, B.C. Bautovich, and D.J. Wimbush. 1973. Forces developed by snowpatch action, Mt. Twynam, Snowy Mountains, Australia. Arct. Alp. Res., 5(2), 121-126.

Curray, J.R. 1956. The analysis of two dimensional orientation data. J. Geol., 64, 117-131.

Dale, M.L. and C.K. Ballantyne. 1980. Two statistics for the analysis of orientation data in geography. Prof. Geogr., 32(2), 184-191.

Dionne, J.-C. 1973. Distinction entre stries glacielles et stries glaciaires. Rev. Géogr. Montréal, 27(2), 185-190.

Dionne, J.-C. 1985. Drift-ice abrasion marks along rocky shores. J. Glaciol., 31(109), 237-241.

Dyson, J.L. 1937. Snowline striations. J. Geol., 45, 549-557.

Embleton, C. and C.A.M. King. 1975. Glacial geomorphology. Second edition. London, Edward Arnold.

Hertzberg, I.N. 1878. Melkedøla. Naturen, 2, 86-87.

Klæboe, H. 1938. Flommene i Mjølkedalen. Nor. Geogr. Tidsskr., 7(3), 113-125.

Liestøl, O. 1955. Glacier dammed lakes in Norway. Nor. Geogr. Tidsskr., 15(3-4), $122-149$.

Øyen, P.A. 1893. Isbræer i Jotunheimen. Den Norske Turistforenings Aarbok, 1983, 50-76.

Rabot, C. 1905. Glacier reservoirs and their outbursts. Geogr. J., 25(5), 534-548.

Rastas, J. and M. Seppälä. 1981. Rock jointing and abrasion forms on roches moutonnées, SW Finland. Ann. Glaciol., 2, $159-163$.

Sars, E. 1869. Melkedalsvandet. Den Norske Turistforenings Aarbok, 1869, 86-90.

Shakesby, R.A. 1985. Geomorphological effects of jökulhlaups and ice-dammed lakes, Jotunheimen, Norway. Nor. Geogr. Tidsskr., 39(1), 1-16.

Sharp, C.F.S. 1938. Landslides and related phenomena. New York, Columbia University Press.

Siegel, S. 1956. Nonparametric statistics for the social sciences. New York, McGraw-Hill. 